\title{
Deleterious GNAQ Gene Mutation
}

National Cancer Institute

\section{Source}

National Cancer Institute. Deleterious GNAQ Gene Mutation. NCI Thesaurus. Code C160879.

A change in the nucleotide sequence of the GNAQ gene that is associated with increased risk of disease. 